\title{
Parasitological analysis of vegetables in a community garden in Teresina
}

Análise parasitológica de hortaliças de uma horta comunitária em Teresina

\section{Alessandra Silva Feitosa, Ana Izabel Sousa Miranda, Erik Damasceno de Sena Lima, Lícia de Sousa Gonçalves, Fernando Luiz Lima de Oliveira}

\begin{abstract}
Vegetables are important for public health, as they may contain protozoan cysts, eggs and larvae of helminths, serving as an important channel for the transmission of enteroparasitosis. Objective: This study aimed to investigate the presence of enteroparasites in some vegetables grown in the community garden. Prince Geovane, in the East Zone of Teresina, Piauí. Method: Ten parts of each plant were collected and analyzed by the methods of Hoffmann and Modified Ritchie, to verify protozoan cysts, eggs and larvae of helminths. Results: In material analyzed by the Ritchie method, as parasite forms were found in 3 of them, as well as in 8 analyzed by the modified Hoffmann method. Conclusion: The result revealed weaknesses in the control of contaminating factors of vegetables, requiring corrective interventions.
\end{abstract}

Key words: Parasitic diseases. Vegetables. Lettuce. Coriandrum. Brassica.

Resumo: As hortaliças são de suma importância para a saúde pública, pois podem conter cistos de protozoários, ovos e larvas de helmintos, servindo como um importante canal de transmissão de enteroparasitose. Objetivo: Pesquisar a presença de enteroparasitos em algumas hortaliças (alface americana, coentro e couve) da horta comunitária Geovane Prado, na Zona Leste de Teresina, Piauí. Método: Foram coletadas dez porções de cada hortaliça que foram analisadas pelos métodos de Hoffmann e Ritchie Modificado, para verificação de cistos de protozoários, ovos e larvas de helmintos. Resultados: No material analisado pelo método de Ritchie, foram encontradas formas de parasitos em 3 deles, bem como em 8 analisados pelo método de Hoffmann modificado. O resultado encontrado revela fragilidades no controle dos fatores contaminantes das hortaliças, necessitando de intervenções corretivas.

Palavras-chave: Parasitoses. Hortaliças. Alface. Coentro. Repolho.

Autor correspondente: fernando@uninovafapi.edu.br

Recebido em 10.03.2018. Aceito em 30.06.2018

http://dx.doi.org/10.5935/1981-2965.20180024

Alessandra Silva Feitosa

Biomédica. Centro Universitário Uninovafapi.Teresina, Piauí,_Brasil.alle_shandra@hotmail.com

Ana Izabel Sousa Miranda

Biomédica. Centro Universitário Uninovafapi.Teresina, Piauí, Brasil. anaizabelsm@gmail.com.

Erik Damasceno de Sena Lima

Biomédico. Centro Universitário Uninovafapi. Teresina, Piauí, Brasil.erik_id45@hotmail.com

Lícia de Sousa Gonçalves

Biomédica. Clínica Biomédica do Centro Universitário Uninovafapi. Teresina, Piauí, Brasil. licia@uninovafapi.edu.br

Fernando Luiz Lima de Oliveira Médico Veterinário. Professor no Centro Universitário Uninovafapi. Teresina, Piauí, Brasil. fernando@uninovafapi.edu.br. Rua Oeiras, 2565, Bairro São Pedro. (86) 999772463. Teresina, PI. CEP: 64.018-020. 


\section{Introduction}

Vegetables are important and indispensable foods in the human diet because of their nutrient content, such as minerals, dietary fibers and vitamins, in addition to their antioxidant action. Generally, vegetables are eaten raw, with lettuce and watercress being among the most used by the population (SILVA et al., 2005; SANTOS et al., 2004; GREGÓRIO et al., 2012).

However, consumers are exposed to the risk of acquiring enteroparasitosis infections by consuming these inadequately sanitized foods that can carry protozoan cysts, as well as eggs and helminth larvae (SIMÕES et al., 2001).

Several studies have revealed the possibility of transmission of enteroparasitoses to humans through foods consumed "in natura", among them giardiasis, amebiasis, ascariasis, teniasis, strongyloidiasis, hookworm and schistosomiasis. The consequences are diarrhea, anemia, hemorrhage and nutritional imbalances (ESTEVES et al., 2009; GREGÓRIO et al., 2012).

Contamination of vegetables by parasites can occur at various points in the production chain. Irrigation with contaminated water, the planting of soils containing human waste and the contact with animals that have free access to the vegetable gardens (TAKAYANAGUI et al., 2006).
Although the ideal consumption of vegetables by the Brazilian population is low, studies indicate that $23.9 \%$ of the population consume them regularly, which is a large contingent (JAIME et al., 2009). The Department of Rural Development (DRD), an organ linked to the Teresina City Hall, administers 57 community gardens, occupying 1,883 lots.

This study aimed to verify the presence of helminth and protozoan forms in vegetables collected in a community garden in the eastern zone of Teresina, capital of Piauí.

\section{Method}

This study is a cross-sectional field research with quantitative approach to verify the possible presence of protozoan cysts, as well as eggs and larvae of helminths in greenery of the Geovane Prado Community Garden, located in the eastern zone of Teresina, capital of State of Piauí. According to the Department of Rural Development (SDR), the garden has an area of 2.8 hectares and 81 lots, and was founded in 1988 by the Municipality of Teresina, which currently has 57 of these gardens totaling 1,883 lots. Parasitological examinations were performed at the Laboratory of Parasitology of the Integrated Health Center (CIS) of the University Center UNINOVAFAPI.

The vegetables selected for analysis were lettuce, coriander and cabbage, as they 
Feitosa et al., Revista Brasileira de Higiene e Sanidade Animal (v.12, n.3) p. 249 -253 jul - set (2018)

were the most commercialized. Three lots of the community garden were selected, where 3 samples from lot 1, 4 samples from lot 2, 3 samples from lot 3 of each type of vegetable were selected, totaling 10 lettuce samples, 10 cabbage samples and 10 coriander samples. Samples were selected in good condition, showing green coloration. Vegetables with rotten leaves, bruised, with yellowish appearance and presence of microorganisms visible to the naked eye were excluded. The parasitological analyzes of the vegetables were carried out according to the method of Hoffmann and Modified Ritchie, used to verify cysts of protozoa, eggs and larvae of helminths.

Due to its simple execution and low cost, as well as its efficiency in the detection of helminth eggs and larvae, we used the method of spontaneous sedimentation of Hoffmann, Pons \& Janer (1934). We also used Ritchie's method modified by Régis Anécimo (MRMRA) to detect helminths and ptotozoa in samples. The Eco-Logic Kit was used to collect and analyze the samples.

In the microscopic analysis, the samples were analyzed using the 10x and 40x objective. The results were presented through tables and data processing involved simple statistics through the Excel 2013 worksheet.

\section{Results and discussion}

Each group of ten samples of each vegetable was analyzed by the two methods, totaling 60 samples analyzed, and 11 samples
(18.33\%) were contaminated with parasite forms, as shown in Table 1. Lettuce and cabbage had a contamination of $6.67 \%$ each, followed by a contamination of $5 \%$ of coriander.

Analyzing each method separately, in 30 analyzed samples, the Hoffmann method found contamination in 8 of them (26.7\%), while the Ritchie method found $10 \%$ contamination in the same samples. Eggs of Ascaris and Taenia sp were found in both methods, whereas the Hoffmann method found cysts of hookworm. All species found cause public health problems for humans.

According to Falavigna \& Faria (2005), lettuce and cabbage are vegetables with propensity to a high degree of contamination because of the shape of their leaves, which are multiple and separated, and with a large area of contact, allowing greater adhesion of certain enteroparasites.

Concerning cabbage, we found an average contamination of $20 \%$, close to $10 \%$ found by Dufloth et al (2013) and 9.5\% in a study by Esteves \& Figueiroa (2009), but far from $63.6 \%$ found by Silva et al (2015) and 100\% discovered by Bento el al (2011).

The mean contamination of coriander samples was $15 \%$ (10\% by Ritchie and $20 \%$ by Hoffmann). Esteves \& Figueiroa (2009) used the Hoffmann method to analyze this vegetable and found 19\% contamination, similar to the result of our study, but Morais (2011) found a contamination of $97.9 \%$, 
Feitosa et al., Revista Brasileira de Higiene e Sanidade Animal (v.12, n.3) p. 249 -253 jul - set (2018)

almost equal to that found in the study of Oliveira et al. (2016).

As we can see, the different degrees of contamination that we find when comparing our results with those of other studies may be due to different methodologies used in each of them.

According to Morais (2011) the contamination does not depend on the

Table 1- Parasitological analysis of vegetables collected at the Geovane Prado Community Garden, Teresina, April 2017.

\begin{tabular}{llll}
\hline & $\begin{array}{l}\text { Ritchie } \\
\text { Modificado }\end{array}$ & Hoffman Modificado \\
\hline Lettuce & $\begin{array}{l}\text { Number of } \\
\text { samples } \\
\text { Contaminated } \\
\text { samples }\end{array}$ & 10 & 10 \\
& $\begin{array}{l}\text { Found forms } \\
\text { Cabbage }\end{array}$ & Taenia eggs & $\begin{array}{l}\text { Larvae of Hookworm } \\
\text { Taenia } \text { eggs }\end{array}$ \\
\hline \multirow{4}{*}{ Coriander } & $\begin{array}{l}\text { Number of } \\
\text { samples } \\
\text { Contaminated } \\
\text { samples } \\
\text { Found forms }\end{array}$ & 10 & 10 \\
& $\begin{array}{l}\text { Number of } \\
\text { samples } \\
\text { Contaminated } \\
\text { samples }\end{array}$ & 10 & 3 \\
& Fscaris eggs & Ascaris eggs \\
\hline & Found forms & Ascaris eggs & $\begin{array}{l}\text { Larvae of Hookworm } \\
\text { Taenia } \text { eggs }\end{array}$ \\
\hline
\end{tabular}

Source: Direct Search.

The $20 \%$ contamination of the lettuce with forms of parasites that we found are close to the $23 \%$ found by Esteves \& Figueiroa (2009). Montanher (2007) and Esteves \& Figueiroa (2009) found respectively $10 \%$ and $58 \%$ of contamination in this vegetable.

\section{Conclusion}

In view of the results, the poor hygienic-sanitary conditions of the studied vegetables grown in the community garden Geovane Prado, southeast of Teresina, are verified, necessitating corrective measures to enable the in natura consumption of these vegetables. Studies are also needed covering other community gardens in our city. vegetable, as suggested to Falavigna \& Freitas (2005) previously, but from the cultivation process to the consumer. Gregório et al (2012) reported that the main factors that influence the contamination of vegetables before harvesting are a use of organic fertilizers, water and soil contamined. 
3. ESTEVES, F.A.M.; FIGUEIRÔA, E.O. Detecção de enteroparasitas em hortaliças comercializadas em feiras livres do município de caruaru (PE). Revista Baiana de Saúde Pública. Bahia, v.33, n.2, p. 38-47, jun. 2009.

4. FALAVIGNA, L. M.; FREITAS, C. B. R. F.; MELO, G. C.; NISHI, L.; ARAUJO, S. M.; FALAVIGNA-GUILHERME, A. L. Qualidade de hortaliças comercializadas no noroeste do Paraná, Brasil. RevistaParasitolLatinoam, v. 60, p. 144149, 2005.

5. GREGORIO D.S; MORAIS G.F.A; NASSIF J.M.et al. Estudo da contaminação por parasitas em hortaliças da região leste de São Paulo. Science in health, v.3(2), p.96-103, maio/ago 2012.

6. JAIME, PATRICIA CONSTANTE et al. Fatores associados ao consumo de frutas e hortaliças no Brasil, 2006. Revista de Saúde Pública, v. 43, n. suppl 2, p. 57-64, 2009.

7. ROCHA, RICARDO EIRAS MOREIRA DA et al. Avaliação de biossólido de águas servidas domiciliares como adubo em couve. Pesq. Agropec. Bras. [online]. 2003, vol.38, n.12, pp.1435-1441. ISSN 0100204X. http://dx.doi.org/10.1590/S0100204X2003001200010.

8. MONTANHER, CAMILA CANASSA; CORADIN, DANIELLI C.; FONTOURA-DASILVA, SÉRGIO EDUARDO. Avaliação parasitológica em alfaces (Lactuca sativa) comercializadas em restaurantes self-service por quilo, da cidade de Curitiba, Paraná, Brasil. Estud. Biol, v. 29, n. 6, p. 63-71, 2007.

9. MORAIS, A.A. de. Avaliação de enteroparasitos em coentro (Coriandrum sativum L) na feira central de Campina Grande-PB. 2011. 15f. Trabalho de Conclusão de Curso (Graduação em Farmácia). Universidade Estadual da Paraíba, Campina Grande, 2011. Perfil parasitológico do cheiro verde comercializado em feiras livres de Imperatriz, MA. Oliveira et al (2016).

10. OLIVEIRA, DARLAN MORAIS et al. Perfil parasitológico do cheiro verde comercializado em feiras livres de Imperatriz - MA. Biota Amazônia (Biote Amazonie, Biota Amazonia, Amazonian Biota), v. 6, n. 2, p. 123-126, 2016.

11. SANTOS, N.M.; SALES, E.M.; SANTOS, A.

B.; DAMASCENO, K.A.; THÉ, T. S. Avaliação parasitológica de hortaliças comercializadas em supermercados e feiras livres no município de Salvador/BA. Ver. Ciências Médicas e Biológicas v. 8, p. 146-152, 2009.

12. SILVA, CELIANE GOMES MAIA DA; ANDRADE, SAMARA ALVACHIAN CARDOSO; STAMFORD, TÂNIA LÚCIA Montenegro. Ocorrência de Cryptosporidium spp. e outros parasitas em hortaliças consumidas in natura, no Recife. Ciência \& Saúde Coletiva, v. 10, p. 63-69, 2005.

13. SIMÕES, MARISE et al. Hygienic-sanitary conditions of vegetables and irrigation water from kitchen gardens in the municipality of Campinas, SP. Brazilian Journal of Microbiology, v. 32, n. 4, p. 331-333, 2001.

14. TAKAYANAGUI, O.M. et al. Análise da cadeia de produção de verduras em Ribeirão Preto, SP. Rev. da Soc. Bras.de Med. Trop., v. 39, n. 2, p. 224-226, 2006. 
Feitosa et al., Revista Brasileira de Higiene e Sanidade Animal (v.12, n.3) p. 249 -253 jul - set (2018) 